\title{
The Problem Analysis and Improvement Measures of Mathematics Education of International Students
}

\author{
Xiaoyan Wang ${ }^{1, a}$, Xuefei Lu $^{2, b}$ and Yanhong She ${ }^{3, c}$ \\ (a,b,c: school of science, xi'an shiyou University, Xi'an, china) \\ a18512262@qq.com, ${ }^{b} 83103401 @ q q . c o m,{ }^{c} 1430317540 @ q q . c o m$
}

Keywords: Foreign students; Mathematics education; Fulll-English teaching

\begin{abstract}
The education of overseas students in China is an important part of talent training, teaching work is the most important part of international students' education, The teaching of mathematics courses for foreign students play an extremely important role in the process of cultivation. This paper analyses the present situation of the mathematics education of the foreign students and puts forward some suggestions, in order to improve the quality of teaching and students mathematical literacy.
\end{abstract}

\section{Introduction}

As the university of science and technology, in recent years, A lot of students from Kazakhstan, Turkmenistan, Pakistan, Yemen, Jordan, Bulgaria, Bangladesh and other countries along the The Belt and Road " came to our school to study. And other students came from South Korea and other countries, This is a good opportunity to seize the" The Belt and Road "construction, and cultivate the global science and technology talents, build a international cultural bridge and enhance our international academic and cultural influence. These students come to our school to choose oil or address and economics major, and mathematics, as the basis of these specialties, has a particularly important role[1].

\section{The present situation of the study of mathematics courses for foreign students}

At present, In our school, the mathematics teaching of foreign students is mainly divided into Chinese and English teaching modes, but The teaching effect is not good. there are a lot of students after repeated make-up still cannot meet the basic requirements of the curriculum. I have taken our whole English higher mathematics and linear algebra teaching for many times[2], In the course of teaching, I have collected feedback from students many times and thought deeply. I think there are the following problems:

\section{The difference in mathematics learning between Chinese and foreign students}

It is be emphasized the logical structure system of knowledge of the mathematics education in our country,and pays attention to the systematicness of knowledge, the perfection of theory, and the cultivation of mathematical skills for students. Through the full training from primary school to high school, our students' ability of logical reasoning, computing ability and spatial imagination is strong in the three basic mathematical foundations, which makes our students have a solid foundation in mathematics and strong problem-solving ability.However, some foreign textbooks are required to be low, although it is very important in the sense of innovation, the foundation of knowledge is weak, the mathematical foundation of innovation and thinking can not be guaranteed[3].Due to economic and cultural reasons, when African students came to China to study, they had less training in computing power and generally poor computing ability. Mathematics calculation mainly depended on calculators. The level of mathematics is uneven. The foreign students from Africa have a uneven mastery of mathematical knowledge. Some students have learned part of the calculus knowledge before they come to China, but some of them have not even learned functional knowledge before they come to China.

\section{Language differences and communication barriers}

Most of the students from different countries and regions came to China. After a short time of 
intensive training, their Chinese level was relatively low and uneven. Some students can only say "hello" "thank you" and a few everyday words, even if some students have passed the HSK 6, but the Chinese level and the understanding ability is confined to the daily communication, has not yet reached the use of Chinese mathematics curriculum requirements[4]. Mathematics course is difficult for Chinese students who are native to Chinese. The result is obviously that the old learning enthusiasm is decreasing gradually, weariness, frequent truancy, vicious circle forming, and little review and preview after class, which can not complete the basic requirements of the course.

\section{Differences in learning habits}

Due to the great difference of middle school knowledge system between foreign students and domestic students, international students' mathematics computing ability is generally weak. For example, some operations in calculating definite integral are needed. But most students need to use calculators to calculate, which is undoubtedly difficult to keep up with the progress of teaching; In addition, foreign students are more expressive in class. Once they have problems, they will ask questions to teachers at any time and interrupt the normal teaching process, which can not meet the higher mathematics curriculum teaching with higher demand for teaching progress. The existing teaching methods and curriculum system of advanced mathematics in China is not very suitable for international students in China[5]. It is mainly manifested in the existing curriculum system emphasizing the foundation of mathematics in middle school, and the overwhelming majority of students from Africa are quite deficient in this aspect. If we teach small classes individually, we can overcome the language barriers, but the negative effects can not be ignored. All of these decide the particularity and complexity of foreign students' advanced mathematics teaching.

\section{The exploration of the educational model}

\section{Improve the professional English level of Teachers}

As a college mathematics teacher, everyone has many years of experience in writing English papers, but classroom teaching in English is a great challenge for mathematics teachers. These require teachers to be fully prepared in many ways: transform the original Chinese knowledge reserve into an accurate English expression, transform written English expression into oral English expression, and gradually adapt to the learning habits and classroom teaching of foreign students. Besides, teachers also need to improve their English level, use their spare time to learn oral English and improve their listening ability, communicate and communicate with foreign students confidently, and learn foreign excellent English lessons by using online video[6]

Understand the customs and religious beliefs of foreign students and strengthen the communication in class

Teachers should properly communicate with students after class. Through communication, teachers can accumulate experience in English conversation with foreign students, understand their basic learning and learning difficulties, and help them solve problems. Meanwhile, teachers should strengthen their understanding of their cultural backgrounds, customs and religious beliefs, and get to know as much interest and educational background of every student as possible. This can greatly eliminate the students' sense of discomfort to the new environment, win the respect of the students, enhance the trust between teachers and students, and promote teaching and learning. In addition, we can organize the Chinese students and foreign students to learn from each other.

\section{Teaching students in accordance with their aptitude and teaching at different levels}

As most African foreign students learning mathematics ability is not the same, it is necessary for the teachers to record the students in the teaching process, according to the mathematical ability and individual differences of students[7]. there are differences in the design of teaching environment and teaching methods, following the principle of individualized teaching for different levels of teaching, giving the different levels of counseling, testing organizations of different levels. In carrying out the teaching process, teachers should pay attention to the individual differences of students, implement differentiated guidance, strive for the full development of students at all levels, and comprehensively enhance the mathematical literacy of international students in China. 


\section{Pay attention to the application of mathematics in life and cultivate students' interest in learning}

Teachers should pay more attention to the application of mathematical knowledge in life and in other subjects. Teachers should be based on students' professional characteristics, selection of examples and exercises and accordingly, to allow students to use mathematical knowledge to solve practical problems in life, so that they gradually realize mathematics is closely related to daily life, so as to cultivate students' theory and practice ability, to cultivate students' interest in learning[8].

\section{The update of assessment methods}

The purpose of the course assessment is to test the effect of learning and to measure the basic requirements stipulated in the syllabus. However, The way of high mathematics closed examination, the difficulty and intensity of general college students are quite incompatible with foreign students. Therefore, we need to combine the characteristics of overseas students to reform examination contents and performance evaluation methods[9]. Concretely speaking, we should focus on the methods of examination, open book, half open book and close book, and weaken the bigger discrepancy arising from weak foundation, so as to maximize the protection of learning enthusiasm of overseas students. To change the single examination mode, combine classroom discussions, homework after class, highlight the evaluation of mathematics learning ability and attitude, so that the results can truly reflect the learning situation, and students can also maximize their subjective initiative in a relaxed environment[10].

\section{Conclusion}

As a special student group in higher education, international students are a new level of education in teaching, which requires constant practice and exploration. The mathematics teaching of foreign students is an important part of the mathematics teaching of the school. Compared with undergraduate teaching and postgraduate teaching, it is a new and waiting area for further development. In the course of teaching, the author gradually explores some methods and techniques suitable for higher mathematics teaching in foreign students. However, due to different cultural differences caused by the source countries, and the conflicts and contradictions resulting from it, the complexity of the teaching of mathematics curriculum of foreign students is determined. The teaching feedback of international students must be constantly analyzed. Actively explore a set of scientific, reasonable, suitable teaching methods and teaching mode, and constantly improve. The best teaching effect can be achieved gradually. In order to ensure the standardization and optimization of foreign students' teaching work.

\section{References}

[1] Jin Weifeng. The problems and Countermeasures of the teaching of all English higher mathematics courses for foreign students[J]. Theoretical observation, 2016, 10: 169-170.

[2] Xu Wenli. Research and Thinking on improving the mathematical ability of foreign students [J]. Guide for scientific and technological innovation, 2009 (34): 134 - 135.

[3] Xia Qing. Thinking of "converging teaching management" model for Chinese educated students coming to China [J]. Educational exploration, 2010 (9): 72 - 73.

[4] Zheng Xiangrong. Analysis of the significance and advantages of the current development of China's overseas students education in China [J]. High education exploration, 2010 (5): 103 106.

[5] Geng Liang. The exploration of advanced mathematics teaching for foreign students characteristics -- problem oriented teaching combined with MATLAB Teaching [J]. Examination weekly, 2015 (82): 48-49.

[6] Summer Qingwen student education in China to develop the strategy of J. Higher education management, 2010,4 (4): 62 - 65.

[7] Li Liguo, Hu Lifang, Zhou Ping. The development trend and strategic choice of studying abroad in China [J]. Fudan Education Forum, 2010,8 (1): 49 - 52. 
[8] $\mathrm{Fu}$ Xueshun. The return to the United States in Mathematics Education [J]. Journal of mathematics education, 2008,11 (3): 33 - 35.

[9] Zhang Meiyun, Some thoughts on strengthening the teaching and management of foreign students in China [J] . Chinese high education research, 2007 ( 5 ) : $68-69$.

[10]Cui Qingling. Existing problems and cause analysis of foreign students education $[\mathrm{J}]$. Chinese high education research, 2008, 25( 1):9-13. 